\title{
Communication
}

[Comunicação]

\section{Winter dysentery in cows associated with Bovine Coronavirus (BCoV)}

[Disenteria de inverno associada ao coronavírus bovino (BCoV) em vacas]

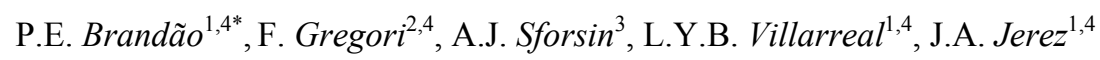 \\ ${ }^{1}$ Faculdade de Medicina Veterinária e Zootecnia- USP \\ Av. Professor Doutor Orlando Marques de Paiva, 87 \\ 05508-270 - São Paulo, SP \\ ${ }^{2}$ Instituto Biológico de São Paulo \\ ${ }^{3}$ Médico veterinário autônomo \\ ${ }^{4}$ Coronavirus Research Group
}

Winter dysentery is an epizootic acute infectious and contagious disease with a seasonal trend that affects adult bovines worldwide, with a higher prevalence in dairy cows, caused by Bovine Coronavirus ( $\mathrm{BCOV}$ ), with cases of association with Salmonella sp, rotavirus, Bovine Viral Diarrhea Virus, Crysptosporidium parvum and Eimeria bovis (Campbell and Cookingham, 1978). The disease was first reported in Brazil in 2002 in a dairy farm in São Paulo State (Brandão et al., 2002).

The annual outbreaks occur during the winter and last up to 10 days, most times affecting $100 \%$ of cows in a farm; affected animals present an acute and severe dysentery, dehidratation, loss of weight and agalacty leading to an average $90 \%$ fall in milk production.

Besides winter dysentery, $B C o V$ also causes diarrhea in newborn calves and respiratory illness in older calves (Heckert et al., 1990; Tegtmeier et al., 1999).

Surveys on the occurrence and etiology of enteric diseases in cows are highly valuable to the control of ongoing outbreaks and to develop more efficient preventive measures to the coming ones, once they allow the depiction of the relations between the occurrence of these diseases and their causes.
This paper reports a survey for $B C o V$ in stool samples from cows collected during outbreaks of winter dysentery using a nested RT-PCR assay targeted to the $R d R p$ gene of the virus and rotavirus using PAGE.

Stool samples were collected from 13 adult dairy cows with dysentery from dairy farms in São Paulo State, Southern Brazil, a region under tropical temperate weather, in May 2000 (1 sample), June 2001 (8 samples) and July 2002 (4 samples). These are fall (May and June) and winter (June and July) months in Brazil. No outbreaks have been reported in these farms in any other month.

Samples were prepared as suspensions in phosphate buffer solution $0.01 \mathrm{M} / \mathrm{BSA} 0.1 \% \mathrm{pH}$ 7.2 (PBS) and clarified by centrifugation $(12,000 \mathrm{xg} / 30$ minutes $)$, the supernatant stored at $-80^{\circ}$ until analysis.

The samples were tested for the presence of $B C o V$ with a group II-coronaviruses-specific RTPCR assay targeted to the RNA-dependent RNApolymerase gene $(R d R p)$ with a 136-bp predicted product (Brandão et al., 2005). BCoV Kakegawa strain (Akashi et al., 1980) was used as positive and PBS as negative controls.

Ten microliters of the nested PCR product were analyzed in $1.5 \%$ agarose gel electrophoresis stained with $0.5 \mu \mathrm{g} / \mathrm{ml}$ ethidium bromide.

Recebido em 26 de janeiro de 2006

Aceito em 6 de junho de 2007

E-mail: paulo7926@yahoo.com 
The 13 samples were searched for rotavirus 11segmented RNA in PAGE (polyacrylamide gel electrophoresis) according to Herring et al. (1982).

All stool samples were found positive to $B C o V$ in the PCR targeting the $R d R p$ gene as described above, evidenced by the appearance of the predicted 136-bp fragment, as seen to the $\mathrm{BCoV}$ Kakegawa positive control. Neither the nested negative controls nor the reactions relative to PBS showed bands. No non-specific band or laboratory contaminations were detected. Furthermore, none of these samples tested positive for rotavirus in PAGE.

The nested PCR used herein was proven to be a useful tool to detect $B C O V$ in stool samples, allowing a fast and reliable diagnosis of this virus, mainly because the $R d R p$ gene is a highly conserved region in genus Coronavirus (Stephensen et al., 1999), where low variation in nucleotide sequence is expected.

The finding of $B C o V$ in stool samples of cows with dysentery, in which no rotavirus was found, suggests that this virus may be a primary agent involved in the etiology of the cases here reported and strengthens the already indicated role of $B C o V$ in winter dysentery. Also, the disease described here has the same seasonal pattern already reported in similar outbreaks
(Alenius et al., 1991; Cho et al., 2000), occurring in winter, cold months.

Furthermore, virus-shedding cows, whether with or without symptomatic enteritis, may serve as reservoirs for calves, in which $B C o V$ is known as a cause of severe neonatal diarrhea (Clark, 1993) which, in their turn, may serve as reservoirs to the adult.

Thus, besides allowing preventive measures against winter dysentery itself, surveys on etiological agents of diarrhea in cows may also provide useful information to the control and prevention of diarrhea in calves.

As a conclusion, winter dysentery was detected during three consecutive outbreaks with the classical clinical and seasonal patterns of the disease and in association with Bovine Coronavirus. Continued studies including other agents, as well as phylogenetic analyses of the $B C o V$ strains found, are being carried out with samples from the surveyed area.

This research was supported by FAPESP (Fundação de Amparo à Pesquisa do Estado de São Paulo). The authors are grateful to $\mathrm{Mr}$. Alexandre Abelardo Sanches for his technical support.

Keywords: bovine, winter dysentery, coronavirus, PCR, diagnosis.

\section{RESUMO}

Descreve-se a pesquisa de $\mathrm{BCoV}$ e rotavírus em 13 mostras fecais de vacas de surtos de disenteria utilizando uma nested PCR dirigida ao gene RdRp e PAGE, respectivamente. Todas as amostras fecais foram positivas para $\mathrm{BCoV}$ e nenhuma delas apresentou-se positiva para rotavírus em PAGE. $O$ encontro de coronavírus bovino em amostras fecais de vacas com disenteria sugere que este vírus possa ser o agente primário envolvido na etiologia dos casos aqui relatados.

Palavras-chave: bovino, disenteria de inverno, coronavírus, PCR, diagnóstico

\section{AGRADECIMENTO}

Ao G.S. Monteleone pela valiosa colaboração.

\section{REFERENCES}

AKASHI, H.; INABA, Y.; MIURA, Y. et al. Properties of a coronavirus isolated from a cow with epizootic diarrhea. Vet. Microbiol., v.5, p. 265-276, 1980.

ALENIUS, S.; NISKANEN, R.; JUNTTI, N. et al. Bovine coronavirus as the causative agent of winter dysentery: serological evidence. Acta Vet. Scand., v.32, p.163-170, 1991.

BRANDÃO, P.E.; BIRGEL Jr., E.H.; GREGORI, F. et al. Bovine coronavirus 
detection in adult cows in Brazil. Arq. Inst. Biol., v.69, p.103-104, 2002.

BRANDÃO, P.E.; GREGORI, F.; VILLARREAL, L.Y.B. et al. A nested polymerase chain reaction to bovine coronavirus diagnosis. Virus Rev. Res., v.10, p.45-49, 2005.

CAMPBELL, S.G.; COOKINGHAM, C.A. The enigma of winter dysentery. Cornell Vet., v.68, p.423-441, 1978.

CHO, K.O.; HALBUR, P.G.; BRUNA, J.D. et al. Detection and isolation of coronavirus from feces of three herds of feedlot cattle during outbreaks of winter dysentery-like disease. J. Am. Vet. Med. Assoc., v.217, p.1191-1194, 2000.

CLARK, M.A. Bovine coronavirus. Br. Vet. J., v.149, p.51-70,1993.

HECKERT, R.A.; SAIF, L.J.; HOBLET, K.H. et al. A longitudinal study of bovine coronavirus enteric and respiratory infections in dairy calves in two herds in Ohio. Vet. Microbiol., v.22, p.187-201, 1990.

HERRING, A.J.; INGLIS, N.F.; OJEH, C.K. et al. Rapid diagnosis of rotavirus infection by direct detection of viral nucleic acid in silverstained polyacrylamide gels. J. Clin. Microbiol., v.16, p.473-477, 1982.

STEPHENSEN, C.B.; CASEBOLT, D.B.; GANGOPADHYAY, N.N. Phylogenetic analysis of a highly conserved region of the polymerase gene from 11 coronaviruses and development of a consensus polymerase chain reaction assay. Virus Res., v.60, p.181-189, 1999.

TEGTMEIER, C.; UTTENTHALL, A.; FRIIS, N.S. et al. Pathological and microbiological studies on pneumonic lungs from Danish calves. J. Vet. Med., v.46, p.693-700, 1999. 